\title{
This is not Marketing. This is HBO: Branding HBO with Transmedia Storytelling
}

\author{
MELANIE BOURDAA, Université Bordeaux Montaigne, Laboratoire MICA
}

\begin{abstract}
This article deals with the way HBO promotes its shows today using strategies of 'transmedia storytelling' (Jenkins 2006). The US pay-per view cable channel has a history of creating a specific promotional system around its programs. Its famous slogan 'It's Not TV. It's HBO.' accompanied the introduction of narrative complexity in shows like The Sopranos (HBO/Brillstein Entertainment Partner, 1999-2007) or The Wire (HBO/Blown Deadline Productions, 2002-8) for example. Transmedia Storytelling, as theorized by Henry Jenkins, is a way to extend stories across multiple media platforms in order to create a coherent storyworld, giving information on characters or insights on the plots and the narrative universe. This article analyses how HBO is developing strategies of transmedia storytelling. I will focus on two specific television shows, True Blood (HBO/Your Face Goes Here Entertainment, 2008- ) and Game of Thrones (HBO/Television 360/Grok! Television/Generator Entertainment/Bighead Littlehead, 2011- ), in order to understand how HBO managed to promote these shows and expand its brand in the American and international television landscape. I use a dual methodology, first presenting an analysis of the transmedia strategies related to the universes of the shows. Then I will draw on interviews with the creators of these strategies in order to understand how they are included in the promotion of HBO.
\end{abstract}

\section{KEYWORDS}

Brand, HBO, marketing, transmedia storytelling.

\section{Introduction}

The American pay-per-view channel Home Box Office (HBO) has a long tradition of putting itself at the centre of a competitive televisual landscape by branding its programmes as something different from what other channels can provide. The branding strategy of $\mathrm{HBO}$, as I will explain in this article, transpires in its motto 'It's not TV. It's HBO.', putting itself above other programming and channels. Recently, HBO has tried new strategies to market its programmes and has decided to include transmedia strategies in order to maintain a certain quality for its members. Transmedia storytelling develops a story across multiple platforms, digital or non-digital, in order to create a coherent storyworld. I will argue that this strategy is useful to create values and a brand for channels and programmes.

This article discusses the new opportunities offered by the use of transmedia strategies by HBO in order to extend its television series and to create a branding culture for the channel. The question I want to tackle is how transmedia is reinforcing the branding of HBO. First, I will explain what 
transmedia is in this context and how it relates to television programmes. Then the notion of quality television, with which HBO is often associated, will be tackled in order to understand what makes HBO stand out in the American televisual landscape. Then, in order to illustrate how HBO is reinforcing its branding strategies today, I will use two case studies, an alternate reality game devised for the promotion of True Blood (Your Face Goes Here Entertainment/HBO, 2008- ) and the transmedia strategy for Game Of Thrones (HBO/Television 360/Grok! Television/Generator Entertainment/Bighead Littlehead, 2011- ). These case studies will be complemented by an interview that I conducted with the manager of Campfire who put together both marketing strategies, in order to show how transmedia could be valuable for a TV channel to promote its programmes and to maintain its brand.

\section{Transmedia and Branding TV}

The notion of transmedia storytelling was first coined by Henry Jenkins, when he analysed the complete storyworld created by the Wachowski brothers around their film trilogy The Matrix (1999-2003). In his seminal work, he defined transmedia storytelling as 'a process where integral elements of a fiction gets dispersed systematically across multiple delivery channels for the purpose of creating a unified and coordinated entertainment experience' (2006, 95-96). The aim is to explode a narrative into chunks on different media platforms in order for the audiences to reconstruct the story. All of the pieces of the narrative have to provide new elements, backstories, or in-depth characters development in order to offer a complete universe for the audience to dive into. For example, in The Matrix, the entire narrative universe is spread across the movie trilogy, a set of comic books with the same title, an animated series The Animatrix (Warner Bros., 2003), two video games, Enter the Matrix (Shiny Entertainment/Atari, 2003) and The Matrix: Path of Neo (Shiny Entertainment/Atari, 2005), and a MMORPG entitled The Matrix Online (Monolith Productions/Sega/WB Games, 2005). The exploration of all the platforms gave the viewers complementary information on the characters, the plots and the relationships. What was interesting in this project is that bridges between the platforms were created, rewarding fans when they engaged in the narration.

Transmedia storytelling in this case was defined in a specific context - that of the Hollywood movie. This implies a strong commercial and economical constraint, which is also present when it comes to TV series. Today, in the movie industry, especially when it comes to blockbusters, each movie is completed with a transmedia strategy that will serve as a promotional tool for the story and/or characters. For instance, before the release of Prometheus (Ridley Scott, 2012) on the big screen, producers and marketers began leaking video of a fake Tedex talk by Peter Weyland, the director of Weyland Industries, the fictional company featured in the movie. A company website was also put online, explaining what Weyland Industries is and giving details on its various activities, among them 'project Prometheus'. Users could even register on the website to gain access to personal only files and discover new contents and clues. Finally, advertisements for David, the Android created by Weyland Industries and an important character in the movie, began showing up on the Internet, giving 'life' to the character. What was interesting in this immersive experience, and what is usually the case in such promotional strategies, is that they create a sense of branding for the franchise. Indeed, developing a transmedia strategy before the launch of a movie sets up the visual identity and tone of the franchise and presents the characters, implementing a 'sense of expectation' (Jost 2006) for the audience. The audience know the movie and its values before watching it on the big screen. 
The strategy of expanding a narrative universe is often used for two main reasons around TV shows. First of all, it allows producers and the channel to promote a show and make it known to the audience before the premiere. Then, it could be used to maintain a regular audience during the hiatuses or between episodes. This is what I have termed the principle of 'augmented storytelling' (Bourdaa 2012). This principle leans on a strong central medium, the 'mothership', with its own characters, storytelling and universe. In this strategy, producers build a faithful and active audience, usually called fans, around their show and then they expand the narration of their series on multiple media platforms. Fans will help spread the media content and make it available in the public sphere. They will play the role of advocates for the series and its narrative. Transmedia strategies rely on fans and fandoms to spread the official content and new information on the franchise within or beyond the community, using social networks and forums to promote the shows. Fans are an important factor in strategies of augmented storytelling, since they will help producers spread the word on the storyworlds, digging every text for clues about characters' backgrounds that they will then share. To show the importance of the audience and especially fans, Frank Rose (2011) talks about the phenomenon of 'deep media', giving fans a place of choice in those strategies. For him, the main element is the receptor, given that the universes created should be immersive and engaging.

Whatever the strategy, transmedia storytelling is part of the branding culture of the channel in the sense that it has to match some criteria defined by the channel in order to fit in with the programming strategy. For example, in 2005 NBC launched a companion website for its programmes which offered some complementary material for its TV shows. In order to promote Heroes (Tailwind Productions/NBC Universal Television Studio, 2006-10), they created tie-in websites for the characters, an interactive web-game and a collaborative fan-fiction, which all matched the standards set up by the production and the channel alike, reinforcing and expanding the narrative but also the branding strategy of the channel (also see Erin Giannini's detailed discussion of product placement in Heroes in the next article in this issue). This website allowed NBC to compete with the other American channels and especially the other networks (ABC, CBS, Fox and the $\mathrm{CW}$ ) and to make its brand even more visible with the display of its logo, its motto, its colours and its programming strategy. They keep developing their enhanced storytelling around their shows like Parks and Recreation (Deedle-Dee Productions/3 Arts Entertainment/Universal Media Studios, 2009- ), Chuck (College Hill Pictures Inc./Fake Empire/Wonderland Sound and Vision/Warner Bros. Television, 2007-12) or more recently The Blacklist (Davis Entertainment/Universal Television/Sony Pictures Television, 2013- ). Jennifer Gillan has called this strategy 'must-click TV' (2011), emphasizing the use of the Internet to enhance the narrative around TV shows and the viewing experience of the audiences. But transmedia is not an entirely new territory for television. ABC has a long tradition of enhancing the narration of their shows since the 1990s, when they employed something of a transmedia strategy around Twin Peaks (Lynch/Frost Productions/Spelling Entertainment/Twin Peaks Productions, 1990-1). They published the diary of the drama's central murder victim Laura Palmer, in which she gives new insight on her life and on who might have killed her. They gave fans the opportunity to dive into the notes of Special Agent Dale Cooper, making them understand his state of mind during the investigation and his progression in chasing the killer. Moreover, they printed a tourist guide of the fictional town of Twin Peaks, giving recommendations for restaurants, sight seeing or hotels, as if the city existed and could be visited. This early strategy, implemented before the use of new technologies by producers and TV viewers alike, symbolised the will for TV channels to give viewers extra information and clues on various platforms, creating an immersive and engaging storyworld. Recently, with the introduction of the Internet in production strategies and viewers' practices, a new strategy arose, called alternate reality games (ARGs). Paul Booth defines ARGs as 'ubiquitous, multimodal and worldwide' (2010, 
17). They provide immersive experiences that enable thousands of players to work together and play at solving enigmas posed by the puppetmaster. They offer a narrative experience for a community of players who will collaborate to find and decipher clues. These ARGs use both the digital world and the real world to create the storyworld, in order to further shatter the border between reality and fiction, since, for example, players can receive mail or text messages from characters from the fictional universe.

\section{Quality Television}

HBO's strategy is to establish its brand as a remarkable one in terms of recognition from the audience and in terms of competition with the other American channels. Its slogan already marked a turning point in the branding of the channel. Indeed, the slogan is famous for making HBO the first channel to promote and propose quality programmes in the early 2000s. For Robert Thompson, writing two years before The Sopranos would first be aired, 'quality TV' refers to specific criteria that HBO would come to include consistently in its programmes, in order to make the channel into a quality brand. These include a certain 'quality pedigree'; the attraction of blue-chip demographics; large ensemble casts; textually, quality TV has a narrative memory, creates 'new genres by mixing old ones', 'tends to be literary and writer-based' and 'is self-conscious'; finally, 'the subject matter of quality TV tends towards the controversial and realism' (Thompson 1997, 14-15). But what is more interesting is the fact that Thompson defined Quality TV as 'not regular TV' (ibid., 13), a definition that HBO reprises in its very own slogan. For example, on HBO, The Sopranos contained a cinematographic approach that was quite new in the televisual landscape at that time. True Blood reinvents the horror genre. HBO puts itself with its shows at the center of the quality trend and brands itself as a quality channel in the American televisual landscape. Its transmedia strategies are therefore built to follow this pattern and provide a quality trend.

The notion of quality television is particularly linked to the implementation of three novelties that have changed the televisual landscape in the early 2000s: the setting of new rules in television production, the appearance of cable channels and the evolution of the use of new technologies in cultural practices. Actually, the Telecommunication Act of 1996, under the Clinton administration in the United States, which intended 'to provide maximum economic and content freedoms for the broadcast industry', broke the rules of the omnipotent networks and made space for the launching of new innovative channels. As Jennifer Holt states, 'the catalyst for this present industrial design has been the striking turn in the political philosophy behind broadcast regulation over the last twenty years' $(2003,11)$. A new era was born. This new era marked the rise of cable television, epitomised by the HBO channel. From its inception, HBO clearly wanted to distinguish itself from mainstream television series, and especially from network television. Mark Rogers, Michael Epstein and Jimmy Reeves (2002) call this new era the 'TVIII era', packed with niche markets, consumer demands and customer satisfaction. From this moment on, HBO has been taking risks in television aesthetics with emphasis on narrative complexity, complex characters and a focus on anti-heroes in the like of Tony Soprano. As Jason Mittell argues, 'the 2000s have been a remarkable decade of transformation in American television. New textual forms have emerged with [...] the pervasive spread of serial narrative across a wide range of fictional formats' (2010). From this decade on, innovation and bold creativity have been exploding on American television and especially on cable channels and pay-per-view stations. HBO brands itself, through its slogan, as the queen channel of experimentation in narrations and storytelling, and has started a new era in television programming. In recent years, new cable channels arrived in the American televisual landscape, competing with $\mathrm{HBO}$ in terms of quality, aesthetics, characters and cinematography. The branding strategy of HBO is now less remarkable since channels like AMC or FX programme shows which possess the same 
characteristics as HBO's series. I am thinking of Mad Men (Lionsgate Television/Weiner Bros./American Movie Classics (AMC), 2007- ), Breaking Bad (High Bridge Productions/Gran Via Productions/Sony Pictures Television/AMC, 2008-13), Justified (FX Productions/TimbermanBeverly Productions/Nemo Films/Rooney McP Productions, 2010- ), and The Walking Dead (Circle of Confusion/Valhalla Entertainment/Darkwoods Productions/AMC, 2010- ), shows that feature anti-heroes, bold narratives and a huge amount of seriality. To stand out as the channel with strong TV shows and to distance itself from the competition of rising premium cable channels, HBO decided to include strategies of transmedia storytelling to promote its shows and strengthen its branding strategy.

\section{The Transmedia strategy of HBO}

As we have already seen, HBO established itself in the American televisual ecosystem as a channel with a clear branding strategy that was signalled in its slogan, in its programming and in its promotional campaigns. As hinted by Mike Monello in the interview I conducted with him, HBO is 'rigorous about its brand and everything they do must live up to its reputation for sophisticated and high quality entertainment' (Monello, personal interview, 2013). Obviously there is a link between their programming strategies and their branding strategy and HBO has to answer to the quality standard that they claim they own. Each of their TV shows possesses quality criteria and are usually quite bold in their storytelling or in their cinematography, being sometimes very graphic in the violence or in sex scenes such as in Game Of Thrones, True Blood or even Girls (HBO/Apatow Productions, 2012- ). And of course when it comes to transmedia tie-ins and strategy, HBO develops coherent narratives with the main series with the respect of a coherent branding strategy.

To illustrate this move by HBO, I will take two case studies created by Campfire: the transmedia strategies around the vampire genre show True Blood and the one around the fantasy show Game of Thrones. I have chosen these series because they are relatively successful in the programming strategy of the channel and both shows fit in with the quality trend established by the channel. Indeed, they are highly serialised, they have complex characters and anti-heroes, they propose new standards in terms of tone and aesthetics and they have a solid fan base. Campfire is a marketing company that has worked several times with HBO and its subsidiary companies like Cinemax in order to promote TV shows and convey in the strategies the branding value of the channels. As described on their website homepage the company 'shapes perceptions and enhances brand preferences through social storytelling, digital content and physical experiences' (Campfire 2014). They build transmedia strategies around TV shows, advertisements or video games (like the Assassin's Creed franchise) to create a branding culture and to shatter the border between reality and fiction. They use social media to spread content and strategies and ask for fans' help. HBO wanted Campfire to enhance its shows on two levels: a narrative one and a branding one. They wanted to give insights on their series, the narrative, the characters and the plots before the programming of the pilot episode. They also wanted to build an immersive strategy, which was faithful to its values and its brand.

True Blood is based on a series of book and depicts vampires living among humans without feeding on them thanks to a beverage made of synthetized blood invented by Japanese doctors. The series is set up in Bon Temps, a small Louisiana town, in a state where racism and fundamentalism is still strong and alive. To launch the show, HBO wanted to create an immersive marketing campaign in order to bring both 'awareness and buzz initially with horror fans, then broaden out to more mainstream viewers' (Monello, personal interview, 2013). According to Mike Monello, creator of 
the marketing campaign, the aim was to set the stage up for the series and give people information about the show that was not covered in the pilot episode. The main strategy was then to 'focus on story because there was a rich opportunity to tell the story of the 'Tru Blood' beverage which wasn't told in the show or even in the novels. Alan Ball, the show creator, was also interested in expanding the story beyond the TV screen' (Monello, personal interview, 2013). The campaign developed an immersive narrative, which imagined, following the premise of the show, that vampires live among humans. But Campfire created two sides: a pro-vampire one, and a convampire one. For each side they introduced characters from the show and characters they created for the campaign who then appeared in certain episodes of the series, webpages presenting both sides, and television ads in order to blur the borders between fiction and reality. They created the beverage, marketed it and sold it in stores and marketplaces to immerse viewers and the audiences into the storyworld of the show.

With this strategy, HBO created awareness around a new genre show and proposed an immersive narrative, which was faithful to its quality branding. Indeed the blurring between reality and fiction symbolized by the actual beverage, the TV ads, the characters appearing in the show and in the campaign as if they were actual people, made the campaign quite successful and immerse the audience in the world of True Blood. The campaign, called 'True Blood: Revelations' acted like a prequel for the show and was divided into three sections. The first one 'Discovery' presented the 'rabbit holes', the clues that sucked the audience into the strategy. Campfire first sent flasks of blood to bloggers, so that they could relay the information about the mysterious package. Starting the strategy by asking influential bloggers to spread the words served as an efficient way to reach a larger audience. A blog written by a 'vampire' and an HBO mock-documentary were also part of this first phase. The second chapter of the strategy, called 'Integration', launched the media battle between pro- and anti-vampires through fake reports, documentaries, interviews and online debates. The synthetic beverage and its huge marketing campaign also appeared at this stage. In stage three, 'Focus', Campfire introduced the characters of the series and the place where it takes place. With this immersive strategy, Campfire managed to introduce the plot and the characters, to shatter the border between fiction and reality by manufacturing and marketing the Tru Blood, by making characters show up in this prequel. And they did this while staying faithful to the branding strategy of $\mathrm{HBO}$.

For Game of Thrones, the strategy was different and the aim was unique to the show. Game of Thrones is also based on a series of books written by G. R. R. Martin. Set in a fantasy historical world, it deals with the kings and queens from the seven kingdoms fighting to take the Iron Throne and reign over Westeros. The show is quite violent and sexually graphic and focuses on the political aspects (treasons and strategic alliances) for the contest to get the Throne. For the transmedia campaign, HBO set up two main objectives. The first one was 'to give context for the story and fantasy world to sophisticated television viewers, and get them to overcome any negative associations with the fantasy genre' (Monello, personal interview, 2013). Fantasy is not an overly typical genre in television and it is often associated with pejorative aspects such as cheapness in special effects, childish plots and a sense of camp. As a quality channel that wanted to programme Game of Thrones, HBO had to overcome these stereotypes and build trust around the series. The second objective 'was to make the epic and complicated story of Game of Thrones more approachable to those who have not read the books' (Monello, personal interview, 2013). The stories of Game Of Thrones are quite complex and sometimes hard to get into, with a huge number of characters that evolve in a place that doesn't exist and that the audience has to imagine and picture. Campfire decided to create a sensorial strategy and used the five senses to present Westeros 
and the characters before the pilot episode of the show aired on HBO. For each sense (sound, taste, touch, sight and smell), they developed a specific material, online or offline, which was supposed to make the audience feel as if they were in the same places as the characters in the series. For example, for the smell, they sent a wooden box to influential bloggers full of perfumes, each representing a place of the kingdoms coupled with a map of Westeros. As in the True Blood campaign, this first move from Campfire acted as a rabbit hole and was rapidly spread on social media by the bloggers. For sight, they virtually rebuilt the wall that separates the kingdoms from the land of the white walkers. Impersonating a Nightwatcher, the Internet user could see past the wall and scan the horizon for possible dangers, like Jon Snow (Kit Harington) does in the show.

Campfire also virtually recreated the Westeros tavern with an immersive 3D sound technology. For touch, they created an application that could illustrate the high temperature differences of the seven Kingdoms. Finally, they partnered with a judge from cooking competition show Top Chef (Bravo/Magical Elves Productions, 2006- ) to create the food flavours of Westeros and delivered them via food trucks in New York and Los Angeles. They even offered a menu with the food. The locations of the truck, which changed everyday, were revealed on Twitter and Facebook. Then, on a second level, for hard-core fans of the books, they created a web-based game The Maesters' Path, in which they could unlock exclusive content and obtain glue stickers. As Mike Monello sums it up, 'Our Game of Thrones strategy focused on world-building, making the fantasy world tangible to help people get a flavour of the show' (Monello, personal interview, 2013). The strategy targeted two different audiences, hard-core fans of the storyworld, and newcomers. Each piece of content had to attract both audiences and make them dive into a fantasy world.

These two strategies are quite different in their objectives and in their narratives. But they both fit within the quality branding and the values of HBO. They are complex, immersive stories, created to blur the borders between reality and fiction and to give insights to the audiences on the shows. They made some bridges between the stories within the show and within the strategy, connecting both narrative elements and creating a unique, coherent storyworld.

\section{This is not Marketing. This is HBO.}

Since its inception in the 1970 s, HBO has been working on building a remarkable brand in order to be competitive in the American televisual marketplace. Starting off the narrative complexity turn in the late 1990s with such shows as The Sopranos, The Wire and Sex and The City (HBO/Darren Star Productions/Warner Bros., 1998-2004), the channel has established some televisual standards for itself and for other channels to follow. They have helped building criteria for quality series: a strong notion of seriality, complex characters, anti-heroes, various aesthetics and cinematography.

With the introduction of more and more seriality and more and more complex characters in TV shows in a competitive ecosystem (especially among the networks), HBO had to come up with new ways to brand its shows and its values. They decided therefore to use transmedia storytelling as a branding strategy and to create an immersive narrative experience for the audience. With shows such as Game of Thrones and True Blood, HBO wanted to appeal to a new genre audience (fantasy and horror respectively) and stay faithful at the same time to its quality motto. They created with Campfire two immersive transmedia strategies in order to present the shows before the airing of the pilot episodes. The aim was to build awareness around the stories and characters by immersing the audiences in the storyworlds. Transmedia strategies for HBO became a branding strategy and a way to promote series on multiple platforms and in an active way for the audience. True Blood and Game of Thrones are not two isolated cases for $\mathrm{HBO}$, as the channel implemented an immersive 
strategy before the beginning of its new drama True Detective (HBO/Anonymous Content/Passenger, 2014- ), a gloomy murder story taking place in Louisiana and starring two movie stars Matthew McConaughey and Woody Harrelson. The mini-series of eight episodes was preceded by an interactive website that set the atmosphere and the tone of the show. Entitled darknessbecomesyou, the interactive website offered the users a first glance at the show, while also offering exclusive and complementary content like police interviews. In this way we can see transmedia strategies are a fixed and important aspect of HBO's promotion of its new productions and its overall brand as a producer of quality drama.

\section{References}

Booth, P. (2010) Digital Fandom: New Media Studies, New York: Peter Lang

Bourdaa, M. (2012) 'Transmedia: Between Augmented Storytelling and Immersive Practices', Inaglobal, 6 September. Accessible at http://www.inaglobal.fr/en/digital-tech/article/transmediabetween-augmented-storytelling-and-immersive-practices. Accessed 25 March 2014

Campfire (2014), CampfireNYC.com, [website]. Accessible at http://www.campfirenyc.com. Accessed 25 March 2014

Gillan, J. (2011) Television and New Media: Must-Click TV, New York: Routledge

Holt, J. (2003) 'Vertical Vision: Deregulation, Industrial Economy and Prime-time Design', in M. Jancovich and J. Lyons (eds), Quality Popular Television: Cult TV, the Industry and Fans, London: British Film Institute

Jenkins, H. (2006) Convergence Culture: Where Old and New Media Collide, New York: New York University Press

Jost, F. (2006) Introduction à l'Analyse de la Télévision, Paris: Ellypses

Mittel, J. (2010) 'Serial Boxes', Just TV, [blog], 20 January. Accessible at

http://justtv.wordpress.com/2010/01/20/serial-boxes/. Accessed 25 March 2014

Monello M. (2013), Chief Creative Officer, Campfire, personal interview with author, November, [email]

Rogers, M. C., Epstein, M. and Reeves, J. L. (2002) 'The Sopranos as HBO Brand Equity: The Art of Commerce in the Age of Digital Reproduction', in D. Lavery (ed.), This Thing of Ours:

Investigating The Sopranos, Wallflower: London, pp. 42-57

Rose, F. (2011), The Art of Immersion: How the Digital Generation is Remaking Hollywood, Madison Avenue and the Way we Tell Stories, New York: W.W. Norton and Co.

Thompson, R. J. (1996), Television's Second Golden Age: From Hill Street Blues to ER, New York: Syracuse University Press 